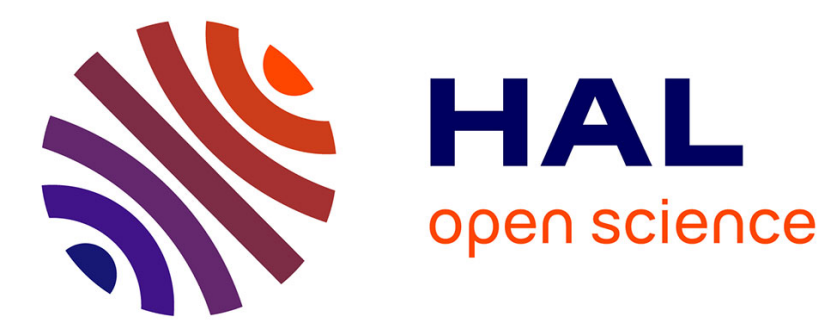

\title{
The Black Sun of the Nilgiris. Astronomy, Photography and Physical Anthropology in South India
}

Marie-Claude Mahias

\section{To cite this version:}

Marie-Claude Mahias. The Black Sun of the Nilgiris. Astronomy, Photography and Physical Anthropology in South India. Visual Anthropology, 2000, 13 (2), pp.129-148. 10.1080/08949468.2000.9966794 . halshs-02427666

\section{HAL Id: halshs-02427666 \\ https://shs.hal.science/halshs-02427666}

Submitted on 3 Jan 2020

HAL is a multi-disciplinary open access archive for the deposit and dissemination of scientific research documents, whether they are published or not. The documents may come from teaching and research institutions in France or abroad, or from public or private research centers.
L'archive ouverte pluridisciplinaire HAL, est destinée au dépôt et à la diffusion de documents scientifiques de niveau recherche, publiés ou non, émanant des établissements d'enseignement et de recherche français ou étrangers, des laboratoires publics ou privés. 


\title{
The Black Sun of the Nilgiris : Astronomy, Photography and Physical Anthropology in South India
}

\author{
Marie-Claude Mahias ${ }^{1}$ \\ Centre d'Etudes de l'Inde et de l'Asie du Sud
}

\begin{abstract}
This article examines how photographs showing Nilgiri people have been brought back to France and deposited at the Museum national d'histoire naturelle in 1872. It leads to recall the circumstances of a scientific mission done by the French astronomer Jules Janssen in South India in 1871. It throws light on the sources and the personal experience of his wife, who published an article in 1882. The importance of photography in the activities and achievements of Jules Janssen was well known. However the snaps he brought back are better appraised in the context of the beginnings of photography and development of its practice in British India. This case also illustrates the relations between photography and physical anthropology.
\end{abstract}

\footnotetext{
${ }^{1}$ Marie-Claude Mahias is a French anthropologist (C.N.R.S., Paris) working on India, who has published on the anthropology of food, the anthropology of technics, and is now doing research on the cultures of the Nilgiri Hills.
} 


\section{INTRODUCTION}

Six photographs from the Nilgiris, dating back from the 19th century, are kept in the photographic library of the Musée de l'Homme, Paris. They are part of a gift of ten photographs, registered on the 31 October 1872 at the anthropology laboratory of the Museum by a certain Janssens (sic), a name written overleaf with a light pencil next to English titles written in ink. The titles written in the entry register tell us that two photographs show Badagas, three show Todas, and two show Kotas, but one of these two last photographs is missing. Consequently, three photographs disappeared before, and a fourth one after being registered.

The author of this gift is Pierre, Jules, César Janssen² (1824-1907), known in his lifetime by his second name. A French physicist and astronomer, he was the first director of the Observatory for Physical Astronomy at Meudon, created for him in 1875 by the then Minister of Education, Victor Duruy. He was also one of the founders of the observatory on Mont Blanc in 1893. A tireless traveller in spite of a limp which had constrained him to a certain isolation during his early childhood, he accomplished numerous missions to near or far off places, from the Peru in 1857 to Vesuvius in 1906, one year before he died of a pneumonia. Appointed to the Académie des Sciences and at the Bureau des Longitudes in 1873, he was honored in many countries and became a member of the Royal Society of London. Foreign biographies as the American Dictionary of Scientific Biography, as well as the many obituaries ${ }^{3}$, indicate the importance of his scientific works, his international reputation, his enterprise, and a broad intellectual curiosity, including, besides his scientific fields, the use of the balloon, aeronautical navigation, photography for scientific investigations, but also lighting in stores and sound isolation of urban housings, all topics which he tackled while teaching physics to architects.

His travels led him twice to the then British India. In 1868 he went to Guntoor, on the coast of Andhra Pradesh, where Jules Lefaucheux, a cotton trader, placed at his disposal the upper part of his house and a wonderful terrace from whence Janssen could observe the solar eclipse on the 18 August. He continued his peregrinations till the end of the year in the Himalayan foothills, looking for signs of the presence of vapor in the spectrum of Mars at Simla, Darjeeling, and Calcutta. The second time he visited South India, in 187,1 on the occasion of the total eclipse of the 12 December, was when he discovered what he named the "coronal atmosphere" of the sun.

\section{THE ASTRONOMER IN THE NILGIRIS}

The circumstances of his travel and of the choice of a station were partly related in the letters that Jules Janssen sent to the Académie des Sciences, and then in his "Rapport..." published in the Journal officiel de la République Française, dated 16, 19 and 29 January 1873.

In July 1871, he had gone to England to visit the main observatories and study their organisation. The British Astronomical Commission invited him to join the mission to India

\footnotetext{
${ }^{2}$ Would I have been interested in this man if his identity had not been revealed to me by Paul Hockings, at Chicago, in April 1994? His generosity should be as much known as his intimate knowledge of the Nilgiris is well established.

I also thank for their agreeable cooperation : Christine Barthe, chargée de mission at the photothèque of the Musée de l'Homme, and Philippe Mennecier, manager of the collections at the laboratoire d'anthropologie physique; Françoise Launay, ingénieur de recherche at the Observatoire de Paris-Meudon, who told me of the correspondance of J. Janssen kept at the Institut de France; and lastly, Catherine Clémentin-Ojha and JeanDominique Lajoux for their enlightened suggestions.

${ }^{3}$ A list of these texts can be found in Janssen 1929-30: 632-633.
} 
which, under the direction of J. Norman Lockyer, was then getting ready to observe the eclipse of the sun that was to occur on 11 December, an eclipse which would be total in Australia, Java, the north of Ceylan and the south of the Indian subcontinent. He at first declined the proposal, and took the advice of the Minister of Public Instruction on his decision. Actually, "it was to be feared that recent events crippled the generous initiative that she (France) has always shown for scientific undertakings"4. Three months of negociations were necessary to interest the main institutions and raise funds in the amount of 27,600 FF, which were contributed by the Académie des sciences, the Bureau des longitudes, the Fonds des voyageurs naturalistes du Museum and the Fonds des missions of the Ministry of Public Instruction. In the event, he had exceeded his grant, borrowed money in India and spent from his own pocket to buy animals and instruments, and so on his return he would request from the same minister an additional allowance of 7,800 FF, which he got without delay ${ }^{5}$.

Once the mission was decided upon, two questions remained: the choice of the instruments and the choice of the place. To answer the first question, Janssen had built a special telescope with high luminous power and a spectroscope with direct vision, in order to observe the spectras of the corona under the best conditions. Considering the climate and the season, the choice of the region was quickly confined to Ceylon (now Sri Lanka) and Hindustan. The choice of the station was still to be made on the spot. Janssen left Marseilles on 15 October 1871, accompanied by his wife as a secretary. He reached Galle, in the island of Ceylon, on 5 November, then inquired, searched, and, after groping around, made his way towards the Indian coast of Malabar and so towards the Neelgherries ${ }^{6}$ (now Nilgiris). Actually, he had to be certain of the transparency of the sky in the morning, at the hour scheduled for the eclipse. Now, he wrote, "as the zone of totality passed over the Neelgherries, I ought to visit them because they seemed to offer very favourable locations, but, at the same time, I was careful to keep in contact with the plain, and to retain the ability to go wherever information might point out the best chances"7.

The British authorities had received orders from England "to ensure the most efficient assistance to the representative of France". Landing in Malabar, Janssen first called on the Governor of the tiny French colony of Mahé, M. Liautaud, and engaged two Indians speaking French and "the idioms of the regions to travel through". He then went from Calicut to Beypour in a bullock-cart, took the railway from Beypour to Coimbatoor, continued his journey in bullock-cart to Mattepollium, a village situated at the foot of the hills, and then had to climb in a sedan-chair for five or six hours to Koonor (Coonoor), and finally continue by car on the metaled road from Koonor to Ootacamund, which he reached on the 26 November. At each stage, he was welcomed by the local British authorities, and in Ootacamund, he was the guest of Mr Breeks, of the Madras Civil Service, the first Commissioner of the Nilgiris. On the strength of the meteorological observations made from 1846 to 1859 in a temporary observatory of the East India Company (Price 1908: 222) and placed at his disposal, he discovered with great satisfaction that "December and January are very fine months, especially the mornings". He traveled through the region in a sedan-chair, took measurements at daybreak which he compared with measurements made on the coast, at Coimbatoor and at Ootacamund, according to his directions, and sent to him daily by telegraph. Finally, he came to a decision: "One sees (...) how the Neelgherries attracted the observer by their fine location on the central line, their height, and their climate, and lastly how the careful study of these mountains led (me) to the most favourable point they could offer". Considering the purity and the exceptional quality of the sky, the direction of the wind and the movements of the clouds,

\footnotetext{
4 "Rapport...." January 16, 1873: 312.

${ }^{5}$ Letter April 24, 1872.

${ }^{6}$ I keep the old script as adopted by each author, what explains variations in the transcription of names of places, languages and groups.

7 "Rapport..." January 19, 1873: 393.
} 
he fixed the exact place of his station "at the North-West extremity of the range, just where the central line crosses the last summits": "I chose my place of observation on a hill at the foot of which lies the Indian village of Sholoor, latitude $11^{\circ} 27^{\prime} 8$, longitude east from Paris, $74^{\circ} 22^{\prime} 5$, a village made of a few wretched huts, the inhabitants of which lived by some meagre cultivation and by working in tea plantations managed by the British" 8 . Jules Janssen settled down in one of these plantations, where his wife was to join him after the eclipse.

Having chosen the location of the station, Janssen had his instruments carried there and a hut built: "Finally, on December 9, three days before the eclipse, the instruments were fitted up and in place". He was not the only astronomer in the region. Not far from him, Col. James Francis Tennant (1829-1915) ${ }^{9}$ and Lieut. John Herschel ${ }^{10}$ had settled on Doddabetta Peak, which reaches $2636 \mathrm{~m}$, and the Italian Lorenzo Respighi was at Poodookotah ${ }^{11}$ (Pudukottai) in the Tamilian plains.

The observation was a success and, the same day, Janssen wrote to the Secrétaire perpétuel of the Académie des sciences: "Only a few moments ago, I just observed the eclipse in a wonderful sky, and still excited by the splendid phenomenon I have just witnessed, I send you a few lines by the Bombay mail which leaves at once" ${ }^{12}$. He extended his stay by one month to take advantage of one of the most beautiful skies he had ever encountered in his journey, to carry out studies of celestial physics in his temporary observatory. Each letter he wrote to various correspondents conveys his enthusiasm for "the admirable purity of the sky of Sholoor". On 19 December, he also wrote to the President of the Royal Astronomical Society to inform him of the main results achieved. His letter is published in the Monthly Notices of the Society ${ }^{13}$, in the same issue, but before the letter of Col. Tennant, dated December 12. This last letter bears testimony of the collaboration of Capt. Morant, Lieut. Herschel, and thanks particularly the photographers J. B. N. Hennessy and Capt. J. Waterhouse, whom we shall meet again later. It seems that the weather conditions were less favorable to the British team than to Janssen, as the morning mist vanished only after the eclipse was already total.

\section{A TRAVELLING COUPLE}

\footnotetext{
8 "Rapport..." January 19, 1873: 394.

${ }_{9}^{9}$ Missing in the biographical dictionaries, he is sometimes mistaken for his father Sir James Tennant of the Bengal Artillery. Even in this period of imperial greatness, a carrier in India did not help for an international reputation.

James Francis Tennant seems to be one of the forgotten names in the history of astronomy. It remembers indeed the simultaneous discovery, by the French Janssen and the British Lockyer, of the bright rays of the prominences in the spectrum of the solar corona, and of their visibility outside of eclipses. To commemorate the event, the French government stroke a medal bearing the effigy of both men, and they became friends. Now, according to an obituary notice signed H. H. T. (H.H.Turner), it is J. F. Tennant who would have given to Janssen "the key which enabled him to see the chromosphere in broad daylight". He was the first to call attention on the favorable occasion provided by the eclipse of 1868, almost two years in advance, in an article to the Royal Astronomical Society (Proceedings of the Royal Society of London, series A, vol. XCII, 1916 : X-XIV). The simultaneity of the discovery by Janssen and Lockyer becomes then easier to explain : both of them had the same source of information, J. F. Tennant. For the eclipse of 1871, when his two colleagues were already covered with honours, Tennant must convince his London friends of the scientific necessity of a costly equipment (Letter to Mr. de La Rue, in Monthly Notices of the Royal Astronomical Society 1869: 284-285). Yet he presided the Royal Astronomical Society from 1890 to 1892 .

${ }^{10}$ Wrongly written as Herschell in the "Rapport..." of Janssen.

11 "Rapport...", January 12, 1873: 394, note 1.

12 "Lettre de Sholoor-Neelgherry, 12 décembre 1871", Euvres scientifiques... I: 236.

13 "Letter from M. Janssen to the President" and "Letter from Col. Tennant to Dr. Huggins", Monthly Notices of the Royal Astronomical Society, vol. XXXII, n 3, 1872: 69-72.
} 
Jules Janssen was surely a man full of curiousity, open to others and endowed with highly skilled hands, an observer and a man of action. While pursuing his astronomical observations, he took interest in his environment and drew, as shown by several of his sketches illustrating the article of his wife (1882). One must know that Janssen, whose father was a musician and whose maternal grand-father was an architect, had as a child shown an aptitude for drawing. He had first intended to take up an artistic career, and attended painting studios till the age of 16.

He carefully watched and described how his luggage, containing breakable and costly instruments, was carried by porters:

The crates were bound with cords and hung from bamboos 3,4, or 5 meters long, according to the weight of the crate; at the ends of these bamboo poles were other smaller bamboos arranged crosswide, allowing the porters to organize themselves in two rows. The big crates needed a dozen proters and arrived in perfect condition, a result which must be credited to their method of suspension which dampened most of the shaking ${ }^{14}$.

The same method of transport would catch the attention of the German technologist Franz Reuleaux, during his travel in India in $1881^{15}$, not because it was locally specific (it had even been described for 18th century Italy), but because it was an ingenious and economic solution to lift and move heavy loads, particularly stone blocs.

As he had to answer all associates' requests, Janssen also kept himself busy collecting living and preserved animals, "intended to fill the many lacunas which had occured during the siege of Paris $\gg{ }^{16}$ for the Museum that had given him 2000 FF. So it was not a question of lacunas revealed by a well-advised management of the collections. These were animals slaughtered and sold as meat during the siege of Paris, that had to be replaced. He fulfilled this mission at Colombo with the help of Mr Layard, a government agent, and at Madras with the help of Lord Napier, Governor of Madras, who offered him "the most distinguished and affectionate hospitality" in the gubernatorial mansion at Guindy. By the end of January 1872, Janssen wrote from Madras and foresaw that he would have to go back to Ceylon to take possession of the collection of animals he had ordered, and then to return to France which he expected to reach by the beginning of $\mathrm{March}^{17}$. He was to bring back about sixty living animals and many species of preserved animals.

Ten years later, in 1882, an article was brought out by Mme Janssen, with the title Souvenirs d'un voyage aux Nilgherries. Les Todas. It is illustrated with eight drawings: four are worked out of sketches drawn by Janssen himself, two from photographs, and the seventh was thought out by the draughtsman from the text. The difference in style is striking, but here I shall be concerned only with the photographs.

Not much is known about Mme Janssen, born Henriette Forestier ${ }^{18}$. Among the many obituary notices written, or read on the occasion of the unveiling of Janssen's statue at Meudon, on 31 October 1920, some paid discret homage to "the modest and sensitive Egeria" who was the "devoted associate of her husband"19. Faithfulness, love, care, are the words repeated to call to mind Janssen's wife and daughter. A faithfulness extended to the professional life as Mme Janssen helped her husband as secretary and assistant, and as she had let him have a part of her house at Montmartre to make into his first observatory (Bigourdan 1920).

\footnotetext{
14 "Rapport..." January 19, 1873: 394.

${ }^{15}$ For the exact references and an analysis of F. Reuleaux's text, see Britta Rupp-Eisenreich 1989: 124.

${ }^{16}$ Letter April 24, 1872.

17 "Lettre de Madras, 27 janvier 1872", Euvres scientifiques, I: 237

18 Born in 1828, daughter of Michel Forestier and Uranie Thierry, Philiberte, Henriette Forestier married Jules Janssen on September 19, 1859, at Paris. Her portrait can be seen in Launay 1997: 114.

${ }^{19}$ Speeches by G. Bigourdan and by M. le Prince Roland Bonaparte, Institut de France, Publications diverses de l'année 1920, 16.
} 
Her article is published in Le Tour du monde. Nouveau journal des voyages, a journal which, according to $\mathrm{H}$. Gaidoz ${ }^{20}$, «owes its public success to the excellence of its engravings $\gg$. Yet, adds the same critic, the statements of the travellers

often need to be checked: if the traveller goes fast, he often sees only the external aspect of beliefs; if he stays and lives amidst an inferior race, he may be tempted and try to get his observations into the frame of his religious theories or philosophical readings. A British critic has pointed out a few months ago that since Mr Tylor's theories are an authority in sociology and anthropology, there are travellers who do not fail to rediscover them among savages; and their descriptions are like what one reads in the works of the British scientist.

Does Mme Janssen avoid this shortcoming, this dual ethnocentrism of the common understanding and of the scientist? Her article is mostly devoted to the Todas. She admits that her interest has been ignited by Breeks. He obtained for her Brother Metz's book, from which she borrowed "a few details on the customs of these tribes"21. So she has got hold of Metz's book and additional informations from Breeks, who offered her hospitality during a fortnight at Ootacamund. But who exactly were these two people? At the time of the Janssens' trip in South India, Revd. J. Friedrich Metz, a German missionary of the Basel Evangelical Mission, had lived in the region since 1847 (i.e. 24 years), exerting himself to preach and convert his "hill-tribes". James Wilkinson Breeks had been posted to the same district for three years, and was to die there six months later. In May 1871, the Indian Museum of Calcutta had requested him to obtain a collection of objects "that will serve to illustrate the habits and modes of life of those indigenous races that have remained little affected by foreign civilization" (Breeks 1873: IV). His quick and enthustiastic answer suggests that he had already a thorough knowledge of the subject, but he still secured the assistance of the same Br. Metz, the inescapable mediator between the natives and any curious traveller. Contrary to the assumption of the Museum officials, Breeks was fully aware that deep transformations had already come about, bringing with them diseases and alcoholism among these "indigenous races". So Metz and Breeks were, at that time, the best experts - indeed the only ones - on the region and its inhabitants. Their written texts constitute the richest evidence (with the exception of Harkness'one which remains the account of a personal adventure) and were the first studies intended to be objective. The greater part of Metz's book is devoted to the Badagas, whom he worked most closely with. Breeks' book, published a few years later, is more systematic, more objective, better balanced, and well illustrated.

What is then the personal contribution of Mme Janssen in her article? She first stayed at Ootacamund, and joined her husband in the plantation near Sholoor only after the eclipse (in any case not before December 9). While he writes to her that he had "everything needed in matter of food"22, she complains that they lived "badly enough, having no other food that mutton and boiled potatoes"23: in short, an English menu! They stay together in the immediate vicinity of the Kota village of Kurgo:j, and not far from many Toda settlements, probably from 13 December 1871 to 12 January 1872, during a period of the year when the most important Kota ceremonies are held. Settled in a plantation where "the coulies understanding the language of the Todas acted as interpreters between these and our servants", the Janssens had quite enough time and opportunity to meet Todas, Kotas and Badagas, to make sketches and to take cranial measurements (to which we shall refer again further). However, Mme Janssen's text hardly conveys what might have been a deep and rich experience. Her evocation of the manners and customs of those whom she just qualifies as "barbarous tribes",

\footnotetext{
${ }^{20}$ H. Gaidoz, "Bibliographie", Mélusine. Revue de mythologie, littérature populaire, traditions et usages, tome II, $\mathrm{n}^{\circ}$ 2, May 5, 1884: 48. H. Gaidoz was one of the two directors of the journal Mélusine, which launched researches on "folk-lore" (sic) in France.

${ }^{21}$ Madame Janssen 1882: 242, note 1

22 Janssen, Correspondance, MS 4133, letter 159 bis.

${ }^{23}$ Madame Janssen, 1882: 242, note 2.
} 
comes straight from Metz and Breeks. Her personal comments are scanty, critical or mistaken. Indeed, she visited a Toda house, and describes it along two paragraphs. She was lucky enough to listen to the characteristic singing of Toda women: "They passionately love to sing in chorus, and willingly let themselves be listened to by strangers ; but what is an honor is not always a pleasure : their guttural voices, without accent or any modulation, are of a sadness and monotony that is altogether disagreeable » $(1882: 246)$

She insists on the isolation and on the difference between these tribes "who never entered into an alliance", whereas such relations were well known to both preceding authors. She did not attend a buffalo sacrifice, thus sparingly described. On the other hand, she certainly saw Kotas returning from one of these sacrifices, and her style changes, becomes a lyrical and even grandiloquent evocation, without compensating for all the poverty of observation and imagination, which brings the reader back to his own familiar feelings.

It was nearly evening; we were at the doorway of our house, watching the setting sun which was of a greater sadness than usual. A distant noise of monotonous singing could be heard and little by little it drew nearer. Soon we could make out a human column, and we recognized the singing of the Kotas. These wild men were laden with quarters of buffalo meat more torn apart than cut up, and all still dripping with the sacrificial blood (...).

As the column passed in front of us, the silhouette of these men, laden with their sinister burden, stood in black against the red of the sky and took on fantastic proportions. (...) It seemed that some infernal beings were filing in front of us, carrying some prey ripped out of the bowels of the earth. When the procession was finished, the sun had set. The humid coldness which descended upon us and the silence which stretched across this scene gave us one of those moments of terror that one experiences while reading the old German ballads... (1882:247-248).

Mme Janssen affects to be frightened before warming herself in front of a clear and crackling fire.

\section{PHOTOGRAPHY IN INDIA}

Jules Janssen, who started his scientific recherch in ophtalmology, became enthusiastic about photography and considered it as a first-rate scientific tool. This led him to have built a "photographic revolver", enabling him automatically to take a series of images of the sun. The French astronomers owe to him their most ancient collections, as well as an Atlas de photographies solaires published in 1903. Several biographers relate his foretelling that "the photographic plate will soon become the true retina of the scientist". He presided over numerous photographic conferences and unquestionably he belongs to the generation of those who saw photography as helpul to scientific research, as a tool able to clear the object of the drosses of subjectivity. After the object became handable, transportable, measurable et classifiable, it lent itself to scientific study as conceived at that time.

But Janssen was not the only one in that case, far from it. The connection between astronomy and photography was common. Col. Tennant himself had tried, without success but then it was the first time - to take a photograph of the solar corona at Goontoor during the eclipse of 1868 . The project he submitted the next year was primarily to fund a large telescope and the use of photography ${ }^{24}$. The telegram he sent to the Royal Astronomical Society, following the eclipse of 1871, pointed out, in spite of its extreme brevity, his success in taking six good photographs ${ }^{25}$. The proficiency of Tennant in matter of photography was to get him nominated as the British delegate to the Astrographical Conference in Paris in 1887. Later still, he became a member of the Royal Photographic Society in 1898, at the age of 69 .

\footnotetext{
${ }^{24}$ Major Tennant, "On the Solar Eclipse of 1871", Monthly Notices of the Royal Astronomical Society, vol. XXIX, $1869: 284-285$.

25 "Letter from Col. Tennant to Dr. Huggins", Monthly Notices of the Royal Astronomical Society, vol. XXXII, n ${ }^{\circ}$ 3, 1872: 70 .
} 
Lieut. John Herschel (1837-1921), who collaborated with Tennant during the eclipse of 1871, was the heir of a name distinguished in both fields: grandson of Sir William Herschel (17381822), a musician and astronomer of great fame, and younger son of Sir John Frederick William Herschel (1792-1871), also a musician, astronomer and pioneer in photography. Evidently great names in the beginnings of astronomy and photography were often the same.

Moreover, the use of photography in India was by no means restricted to astronomy. Ray Desmond retraced with precise details how photography spread all over the subcontinent a very few years after its invention in Europe. A number of army officers and surgeons enthused over this new hobby. The first photographic society was founded as early as 1854 at Bombay, and two years later those at Madras and Calcutta came into being. Furthermore, the East India Company quickly saw how to turn such a tool to the best account and, as early as 1855 , the cadets of the military academy of Addiscombe were being trained in this field - as were the missionaries in Basel. Photographic practice was offically enjoined to register the progress of public works, to index ancient sculptures and monuments, to oversee criminals, so that draughtsmen, being slow and costly, soon made way for photographers. Professionnal studios were opened in the main towns, so great was the demand : in India as well as Britain, Indian images fed the imagination of colonial glory and the desire for tropical picturesqueness. These commercial businesses paid particuliarly well in government headquarters like Simla, the summer resort of the Viceroy, or Ootacamund, where the Madras Government had its summer quarters from 1870.

In 1856, Capt. Linnaeus Tripe was appointed official photographer to the Madras Presidency. His duties added training to the photographic recording of everything that existed in the way of objects, monuments and "races". During the monsoon, he taught the calotype process to employees of the Public Works Department, and the collodion process to pupils of the Madras School of Industrial Arts. During the remaining months, he travelled through the country. The job would be cancelled after three or four years, but this was sufficient time to enable Tripe to publish six volumes in 1858 , containing more than a hundred photographic views of several places (Desmond 1976: 20). His teaching was also effective, seeing that the quality of the works done by his students at the Madras School of Arts was to impress Samuel Bourne very favourably, when he reached Calcutta in 1863.

By the end of the 1850s, Lord Canning, Governor-General and first Viceroy of India, and Lady Canning, both of them fond of photography, sponsored a photographic compilation of the country and its inhabitants. Fifteen photographers collaborated, among whom was J. Waterhouse, the same one who was to assist the colonel-astronomer Tennant at Dodabetta Peak in December 1871. The result of this image-hunting, enlarged with another collection bearing on the Eastern Bengal, was published by the India Office in London between 1868 and 1875, with the title The People of India : eight volumes of 468 photographs along with short descriptive captions, to illustrate the "Races and Tribes of Hindustan". In this monumental work, photographs of the Nilgiri people (vol. VIII, 1875: 430-440) have not been attribued to anyone. Those of Toda and Kota women are good-quality studio photographs, but they have been inverted in relation to the captions.

Professionnal photographers were settled at Ootacamund from 1864 at the latest. J. H. Kenrich seems to have been the first and he would stay till 1876, excepting the four years 1869-1873. Capt. Edmund David Lyon would join him two years later, in 1866. Lyon, who stayed in India from 1865 to 1871, was commissioned by the Madras Government to photograph ancient monuments of the Presidency (Desmond 1976: 23). His stay during four years at Ootacamund, 1866-1870, was part of a far-reaching project, which led him to travel throughout the region. Samuel Bourne, who arrived in India in 1863, had already scouted Himalayan regions when he visited the Nilgiris in 1867. His reputation as a very great professional was already firm, and he was admired as much for his technical achievements as for the artistic quality of his photographs. In 1870, Lyon was replaced by the Nicholas 
Brothers, photographers already settled in Madras for ten years, who would stay at Ootacamund till 1875 ; and, in 1871, J. Boesinger settled there for twenty-five years. Great commercial photographers like A.T.W. Penn or Wiele \& Klein would arrive later, respectively in 1876 and 1894 .

As one can see, photography in India, particularly in the Madras Presidency where the Nilgiris were situated, had already a fairly long and rich history when the Janssens got there in 1871. It was systematically used to illustrate topography, architecture or ethnology in its infancy. Professional glass negatives of high quality were easily available at Madras and even at Ootacamund.

It is no surprise that Jules Janssen foresaw pictures as possible documents for other sciences. Notwithstanding his interest in photography, the astronomer did not take photograph of, but sketched, what he observed outside his professional duties. Then whence come the photographs he brought back? These are snaps posed but not really composed, with set attitudes, showing faces hardly comfortable if not really uneasy, as was often the case at that time. The pursuit of photographs avoiding stiff poses, for documenting activities or ceremonies, would only come later, at the turn of the century (Hockings 1992: 183). Nevertheless, the large size combined with moderate quality (three are rather hazy) seem to point to the material being used by someone without the skill of a professional.

One drawing from a photograph, which illustrates Mme Janssen's article ("Types of Todas", $1882: 245$ ), possibly provides material for an answer. First of all, this drawing recalls one photograph excluded from the gift to the Museum. Moreover, it reworks exactly the same composition and the same characters as Pl. III in Breeks' book, adding in the middle a girl who appears also on Pl. IV of the same book. One is justified to infer that the photograph used as a model is part of the same series as Breeks's photographs, and therefore comes from his collection. If this only sure case allows for any generalisation, the simplest explanation would be that Breeks himself gave a few photographs to Janssen. One better understands the critical opinion quoted in the foreword of his book about the second-rate photographer "whose performances were by no means satisfactory", according to him. It is known that Breeks wished to furnish the Government "with the information they desired [...] and [...] a very complete set of photographs", but "no good photographer, however, was willing to supply these at a reasonable rate". Whom had he asked ? Perhaps Nicholas Brothers, the only studio photographer living permanently at Ootacamund in 1871 ? This is not known, but the British administrator had to fall back upon a photographer of the School of Arts of Madras and could only get illustrations which seemed to him "indifferently executed" (Breeks 1873: iii).

The second drawing from a photograph in the same article ("The Kotas", 1882 : 248) agrees exactly, at least concerning the subject, to the photograph which is missing at the Musée de l'Homme with the title: "Group of Kota men". Yet one cannot be certain that it is the same photograph. Probably a deeper knowledge of the subject would be necessary to identify more certainly the author of the photographs brought back by Janssen. I can only leave these questions outstanding.

\section{PHYSICAL ANTHROPOLOGY}

One knows the complicated relations between photography and physical anthropology, the various and sometimes opposite interpretations to which they may have led (Pinney 1992). At first, they were not only contemporary. They backed each other up, adding their means and effects to see, objectify, seize and reduce human beings into a series of visible and measurable features.

In 1873, Col. William E. Marshall published a book entitled A Phrenologist amongst the Todas, or the Study of a Primitive Tribe in South India. It was the outcome of an enquiry 
he had made in the course of a furlough taken at the sanatorium of Ootacamund in 1870 , in constant association with Revd. Metz, who helped the author with his knowledge of "the Toda dialect" and with the personal respect in which he was held by the people. The text is illustrated with 26 photographs, for which the author thanks the skill of the " distinguished artists » Messrs. Bourne and Sheperd, of Simla, and Nicholas and Curths, of Madras. A dozen autotypes show people, as portrait or full-length, some of them against a rectangular grid.

Soon after its publication, the book was reviewed by Armand de Quatrefages de Bréau, one of the founders of physical anthropology in France, which was then the heir of zoology, defined as the "natural history of man". The review was exceptionaly long, made of three articles totaling 43 pages.

Quatrefages considered phrenology as "a doctrine definitly judged and condamned by science" (1873: 732), and he pinpoints the biases of the author : "The Colonel has his ideas formed on the beginnings of humanity, on the stages it must have passed through, on the persistence of certain primitive types. He also refers all his conceptions to phrenology, and always displays his care to make all craniological characteristics agree with the least circumstances of the way of life. It is difficult, while reading many a passage of his book, not to think that he may have let himself not to see among the Todas such and such quality the bump of which was missing in their dolichocephalic skull" (1874: 101). Moreover he blames Marshall for not having taken a few precise measurements of these skulls with such eloquent shapes.

Nonetheless he considers the study of the Colonel of the utmost interest, since both men meet on the common ground of research and classification of races, even if their conception of those races is divergent. Marshall is indeed convinced that the Todas are the inaltered remains of a branch of the "Dravidian race ", which came from Western Asia. They would constitute a surviving sample of the "Turanian race » in its very primitive stage, close to the Ethiopians to judge by their style of life, to the Jews and to the Chaldeans by their appearance. Quatrefages, leaning on Hamilton Smith ${ }^{26}$ to whom he gives credit for having disentangled the "inextricable jumble of races" in India, is already informed that travelers have always been struck by the difference established by their physical features, language, and manners, between the Todas and the surrounding populations (Quatrefages 1873: 732). For him, a polygenist looking for unknown or lost "races", it is as the representatives of an exceptional type that Todas deserve all the attention of anthropologists : "Though Todas may have played only a minor part in the constitution of the obviously mixed races of India, they nonetheless constitute an ethnological component of these races, and it is truly good luck to be able to study this component in a state of purity" (1873: 738).

His interest was not accidental. He admired Adolphe Pictet, who knew the Celtic and Sanskrit languages, and invented an ethnology of the Aryas, whose perfect language could only reflect an ideal state of humanity (Olender 1989: 134). Besides the theories of the British scientists meant for explaining the Indian populations, he knew Major W. Ross King's booklet on the Nilgiri tribes, published in 1870 by the Anthropological Society of London. To compare with the informations and illustrations provided by Marshall, he also had at his disposal several photographs and cranial measurements brought back by Jules Janssen in 1872 (1873: 742). That then is whom the documents brought back by the astronomer were intended for! The description given by Quatrefages apparently mentions at least four photographs of Todas, among which three showing respectively seven men and eight women in full-length, with their heads rather unsuccessful and too pale, and a portrait of a young man with his beard cut. Could these be the three photographs given to the Museum but not registered?

These photographs are precious for Quatrefages who, thanks to them, can judge by himself the accuracy of the descriptions given by Marshall, and even complete them in some

\footnotetext{
${ }^{26}$ Natural History of the Human Species, 1848.
} 
details. Like Janssen, he thinks that the eye is the best instrument for scientific observation and that photography can only improve its accuracy. One sees how the use of photography contributes to constituting the human being as a zoological individual, to reduce relevant features to the conspicious physical features only, whereas, in the beginnings of physical anthropology, the criterion of classification of races combined physical features, ways of life, social organisation and spoken language. Besides, Quatrefages does not avoid what he blames Marshall for : submitting facts to his own prejudices. As he wants to constitute the Todas as a race "in a state of purity", he selects what is of interest for him. For example he regrets that, on Janssen's photographs, individuals are "all draped in the kind of blancket which they use as dress". On the other hand, the clearness of the autotypes printed in Marshall's book, showing men "in foot almost naked", enables the scientist to draw his own conclusions on "the beauty of the Toda type", to state that the Toda head "perfectly deserves the adjective harmonic", and that the villosity of the face and of the body is the feature which isolates Todas most clearly from other Indian populations (1873: 744-745).

Did Janssen bring these photographs and these measures just by chance ? Though Quatrefages and Janssen shared the same taste for mathematics and drawing, and though both of them were elected to the Académie des sciences, after an interval of twenty years, they did not know each other personally at that time. They entered into direct relations only ten years later, in 1881, when Mme. Janssen sent her article to Quatrefages. Quatrefages first returned a very polite answer, and then sent her two of the three papers he had himself published seven and eight years earlier ${ }^{27}$. Here is proof that the Janssens did not know about them. One must therefore consider the deposit of photographs at the Museum as being just an aspect of good professionnal relations between scientists belonging to different institutions. Likewise, in July 1873, when the little baboon he had brought back from Hindoustan had just died, Janssen had the body taken to the laboratory of Henri Milne-Edwards, so that it could be "of some interest to the Museum, either as skin or as skeleton", begging that, in case it would not, it should be taken to the laboratory of M. Broca, at the Medical School ${ }^{28}$.

\section{CONCLUSION}

The circumstances of the mission in India of the French astronomer Jules Janssen bear testimony to the relations between scientists of different fields in the 19th century, as well as to the prominent place of the Museum for all the scientists obliged to travel, whatever their speciality. An unfortunate consequence is that, sometimes, great names gave weight and credibility to what involved a good amount of amateurism. In the field of the Nilgiri Hills, the strategic position of the missionary J. F. Metz was already well known. To his help as a mediator and an interpretor, which J. W. Breeks and W. E. Marshall were nor the last ones to call upon, one must now add the influence of Metz's book on Mme. Janssen's article.

It has also been shown that, concerning the first inhabitants of the Nilgiris, Europeans have all the more reinforced the conception of tribes as isolated, primitive and savage, since they were distant, whether through geography or institutions (Mahias 1997). Quatrefages and Mme. Janssen, in their own ways and for different reasons, stressed the strangeness, the archaicness and the isolation of the Todas and Kotas. The qualification of these groups as primitive and savage tribes was indeed necessary to strengthen the historicist vision of the Indian population. This theory inferred that groups speaking Dravidian langages were a relic of a state prior to the arrival of the Aryans, Hindus and organised in castes. What a godsend to find just such groups living in hilly regions, difficult of access! The comparative isolation seamed to vouch for the fact that they never mixed with populations that had arrived more

\footnotetext{
${ }^{27}$ Quatrefages, Correspondance de Janssen, MS 4136, letters 447 and 449.

${ }^{28}$ Janssen, Letter July 4, 1873, Museum National d'Histoire Naturelle, MS 2755.
} 
recently, and that they truly represented inaltered remnants of otherwise disappeared races. Mme. Janssen published her article ten years after she had travelled in India. She had met the best authorities on the region and she could make first-hand observations. Nevertheless, the distance in time and space led her to reinvent tribes which would never have had any link between them, and to qualify the Todas as "barbarian" tribes, "masters and lords of the soil, isolated and idle near their revered herds". The Kotas, at first "savage men", become in her account "fantastic apparitions", then "infernal beings" sinking into the bowels of the earth. Her article, translated in German the next year, surely profited by the reference and the authority of a name well known in academic circles as hers.

Beyond the particular Nilgiri case, it is the constitution of physical anthropology as a scientific discipline, and its endeavors to broaden the gap between theoretical models and empirical object, which change this object, even though it were a set of human societies, into an inanimate object. The use of photography is a means and an indicator of this approach. One recognises the methods brought to light by Bruno Latour (1993), when he scrutinizes pedologists studying a part of the Amazonian forest, and looks more widely at "science in action". Quatrefages does not need to move about and set out in search of diseappeared or forgotten tribes, whose existence is assumed by his theory. Another scientist (and any tourist might have done) can bring him back useful informations, on paper. Photography becomes one of the means to reduce the world to two-dimensions images, superposable, comparable, measurable, by the scientist, who thus can believe and make believe that he controls this world. Just like the core-samples of the pedologists, photography allows on to deprive transfered data completely of their context, to remove a number of dimensions, which are by no means thin in the case of human beings, and to change a society into a collection of bare individuals. Dress itself, recorded with no malice in the photos, is considered cumbersome by the dehumanising eye of the scientist.

Bruno Latour's argument also calls attention to the part played by the photographic illustration in the constitution of any scientific text, as it includes the referent of the narration in the text itself. Indeed, photographs do allow Quatrefages, a better established scientist, to judge Col. Marshall, endowed with less scientific if no less military fame, to confirm his observations or to critisize him, and not without condescension.

But, if the characteristic of any science is to built artificial representations that withdraw from the real and in the same time enable one to produce certainties, then Janssen's attitude appears nothing less than unscrupulous. The astronomer used photography as a means necessary to his own scientific investigations and knew from experience the worth of an image, its value as proof in a demonstration. Besides, he had practiced photography long enough to know that the pictures he brought back were of poor quality. Photographs were already readily available in Ootacamund and Madras, and he could surely have found better ones. He remembers his French colleagues, but this interest remains minor for him.

Moreover, that some material and intellectual procedures are comparables in fields as different as astronomy, geology and physical anthropology, throws into relief the dissymmetry between the status of observation and the status of theory, as well as the disproportion in the means and efforts brought into play. The scientist-astronomer applies himself to his object, the sun, to catch its images. He chases it to the ends of the earth if necessary, carries out empirical observations, sparing no trouble to create the best possible conditions, himself checks each link of the scientific production, which will enable him to get new informations. The physician-naturalist-anthropologist, who publishes on lower marine life or silk-worm as well as on human beings, remains an arm-chair and laboratory scientist. His readings are subjected to the grid of preconceived theories, documents are used without criticism : he puts on the same level photographs the origin of which he does not know, the article of Mme. 
Janssen, and other publications by "British scientists, missionnaries, majors or colonels" ${ }^{29}$. He considers all of them as being equivalent sources of information. Urbanity does not prescribe such a lack of curiosity and exactness. The "human races", forgotten or disappeared, do not concern him so much as to go and inquire for himself. They are a frame of thought into which no field observation may enter to disturb him.

\section{REFERENCES}

Asylum Press

1861-1875 Almanac and Compendium of Intelligence (The). Madras: The Asylum Press. Breeks, James Wilkinson

1873 An Account of the Primitive Tribes and Monuments of the Nilagiris. London: India Museum, 137 p. + LXXXII plates. Reprint : Delhi: Cultural Publishing House, 1983.

Desmond, Ray

1976 Photography in India during the nineteenth century. India Office Library and Records, London: 5-38.

1982 Victorian India in Focus. A selection of early photographs from the collection in the India Office Library and Records. London: Her Majesty's Stationery Office.

Hockings, Paul

1992 The Yellow Bough: Rivers's Use of Photography in The Todas. In Anthropology and Photography 1860-1920. E. Edwards, ed. Pp. 179-186. New Haven and London: Yale University Press, in association with the Royal Anthropological Institute.

Janssen, Jules

1873 Rapport relatif à l'observation de l'éclipse du 12 décembre 1871, adressé par M. J. Janssen au ministre de l'instruction publique. Journal officiel de la République française, January 16, 1873 (pp. 312-313), January 19, 1873 (pp.392-394), January 20, 1873 (pp. 408-409).

1929-30 Euvres scientifiques, recueillies et publiées par Henri Dehérain. Paris: Société d'éditions géographiques, maritimes et coloniales, 2 tomes.

n.d Janssen, Archives Nationales, Série Sciences et Lettres, F17-2977.

n.d. Janssen, Lettres, Museum National d'Histoire Naturelle, MS 2755.

n.d. $\quad$ Correspondance, Institut de France, MS 4133-4136.

Janssen, Madame

1882 Souvenirs d'un voyage aux Nilgherries. Les Todas. Le Tour du Monde. Nouveau Journal des Voyages. Paris: Librairie Hachette/Londres: King William Street, Strand.

King, W. Ross

1870 The Aboriginal Tribes of the Nilgiri Hills. London: Longmans, Green, and Co. (A paper read before the Anthropological Society of London, May 3, 1870 and published by the Society in the Journal of Anthropology).

Latour, Bruno

1993 Le "pédofil" de Boa Vista - montage photo-philosophique. In Petites leçons de Launay, Françoise sociologie des sciences. Pp. 171-225. Paris: La Découverte.

\footnotetext{
${ }^{29}$ Quatrefages, Correspondance de Janssen, MS 4136, letter 447.
} 
1997 Autour de l'éclipse totale de soleil visible en Inde le 12 décembre 1871. Le voyage du couple Janssen aux Neelgherries. L'Astronomie, vol. 111: 111-115.

Mahias, Marie-Claude

1997 The Construction of the Nilgiris as a "Tribal Sanctuary". In Blue Mountains Revisited: Cultural Studies on the Nilgiri Hills. P. Hockings, ed. Pp. 308-327. Delhi: Oxford University Press.

Marshall, William E.

1873 A Phrenologist amongst the Todas or the study of a Primitive Tribe in South India. London: Longmans, Greens, and Co. Reprint: The Todas (Their Ethnography and History). Gurgaon: Vintage Books, 1989.

Metz, Reverend Friedrich

1864 The Tribes Inhabiting the Neilgherry Hills; their Social Customs and Religious Rites. From the rough notes of a German Missionary. Second enlarged edition,

Olender, Maurice Mangalore: Basel Mission Press.

1989 Les langues du Paradis. Aryens et Sémites: un couple providentiel. Paris: Gallimard/Le Seuil.

Pinney, Christopher

1992 The Parallel Histories of Anthropology and Photography. In Anthropology and Photography 1860-1920. E. Edwards, ed. Pp. 74-95. New Haven and London: Yale University Press, in association with the Royal Anthropological Institute.

Price, Sir Frederick

1908 Ootacamund. A History. Madras: Superintendent, Government Press.

Quatrefages de Bréau, Jean-Louis-Armand de

1873-74 A Phrenologist among the Todas... By William E. Marshall, Lieutenant Colonel of Her Majesty's Bengal Staff Corps, London 1873. Journal des Savants, December 1873: 729-745, January 1874: 5-22, February 1874: 96-106.

Rupp-Eisenreich, Britta

1989 Le savoir technologique de l'Orient. A propos du Voyage en Inde de Franz Reuleaux en 1881. Techniques et culture 14: 109-132.

Watson J. Forbes \& John William Kaye (eds)

1868-1875 The People of India: A series of photographic illustrations, with descriptive letterpress, of the Races and Tribes of Hindustan. London: India Museum, 8 vol.

References to Journals of astronomy refered to in the notes have not been listed here. 